eight. He was apprenticed to his father James Powell Swift (1826-1906), who founded the original firm, and who himself served as an apprentice with Messrs. Ross, Ltd. He was a fellow of the Royal Microscopical Society for thirty-six years.

The interest in scientific and optical instruments displayed by the three members of the firm mentioned above goes back yet one more generation. Thomas Swift (1799-1882), father of James Powell Swift, although at one time a hosier in Fenchurch Street, London, was sufficiently interested in scientific instruments to open such a business in Bendigo, Australia, where many microscopes were sent out to him by his son.

With such a background, the name of Swift will doubtless continue to be associated with optical instruments and microscopes of high quality.

B. K. JoHnson.

\title{
NEWS and VIEWS
}

\section{Prof. D. B. McQuistan}

Prof. D. B. McQuistan, who recently retired from the Freeland chair of natural philosophy in the Royal Technical College, Glasgow, has now, through failing health, been forced to relinquish a lifetime devoted to the cause of education. A brilliant student of the University of Glasgow, he was awarded the Thomas Logan Memorial Medal and Prize for the most distinguished graduate in arts of his year, with first-class honours in mathematics and natural philosophy, and in classics. The William Houldsworth research studentship afforded him the opportunity of spending a profitable year at the University of Cambridge, and, along with his later services as a mathematical teacher, he was well equipped for the duties of the chair which he afterwards occupied with great distinction. Many thousands of students will remember with gratitude his lucidity as a lecturer, and his exceptional aptitude in clarifying any difficult mathematical or scientific complexity. His popular lectures of scientific interest to varied audiences were an inspiration to the expert and a delight to the novice.

On his retiral, Prof. McQuistan was chairman of the Board of Studies at the Royal Technical College, and for many years he did invaluable and onerous work as convener of the Business Committee of the General Council of the University of Glasgow. His colleagues in the Dumbartonshire Education Authority will undoubtedly miss his unfailing and ungrudging service. His logical mind and calm temperament were always conducive to wise decisions. With unerring instinct he foresaw the possibilities of the film as an aid to education, and was convener of the Advisory Committee on the Production of Educational Films, under the auspices of the Scottish Film Council. Prof. McQuistan's present absence from active participation in educational matters creates a void, and his many acquaintances will cherish his great teaching qualities, his brilliant intellect, and, above all, his charming and lovable personality

\section{Ignaz von Born}

ON December 26 occurs the bicentenary of the birth of Ignaz von Born, one of the first to realize the great part fossils were to play in historical geology and the first to describe the use of mercury in the extraction of gold and silver. Borm at Carlsburg in Transylvania, he was educated at Hermannstadt and
Vienna, and studied law at Prague. He then made a journey through Germany, Holland and France studying the minerals, mining, etc., and a year or two later made another mineralogical journey through Hungary and Transylvania. An account of this second journey, in the form of letters, was published in 1774 by the Swedish mineralogist, J. J. Ferber (1743-90). At Prague, where he held a post as mining councillor, Born assisted in forming a scientific society. In 1776 he was called to Vienna by the Empress Maria Theresa to arrange the natural history collections, which he afterwards described in a fine work. $\mathrm{He}$ continued to reside at Vienna until his death on July 24, 1791. One of the last of his books was his "New Process of Amalgamation of Gold and Silver Ores ...."

Born's "Travels through the Banat of Termeswar, Transyl. vania and Hungary" and his book on "Amalgamation" were translated into English by a clever but unscrupulous German, Prof. Rudolf Erich Raspe (1737-94), who after stealing coins from the collections at Cassel fled to England, where he was already a foreign member of the Royal Society. After a period Raspe's name was struck off the rolls of the Society and he took to writing for a living, and while acting as storekeeper and assayer at Dolcoath Mine in Cornwall wrote the original part of "Baron Munchausen's Narrative". Later on, Raspe obtained money from the public-spirited Scottish baronet, Sir John Sinclair (1754-1835), by pretending to discover gold and silver on his estate at Ulbster, Caithness, an incident com. memorated by Scott's character "Dousterswivel". Sinclair, it may be added, was one of the subscribers to Raspe's translation of Born's "Amalgamation"

\section{Research on Coal Utilization}

Sir Evan WrLuIams announced, in his presidential address to the British Coal Utilization Research Association on December 17, that a scheme utilizing $£ 1,000,000$ in five years for research on coal has been prepared. He said that this is by far the largest co-operative research scheme ever undertaken in Great Britain for the development of an industrial asset. The scheme has been approved by the Department of Scientific and Industrial Research, which has undertaken to contribute $£ 50,000$ a year to the cost, and $£ 250,000$ over the five years. The Mining Association will contribute $£ 80,000$ a year and $£ 400,000$ 